\title{
Yaban Hayvanı Uyarı Levhalarının Konumlarının Değerlendirilmesi Kırıkkale-Çankırı Karayolu Örneği
}

\author{
Ali Uğur ÖZCAN ${ }^{1}$,Nuri Kaan ÖZKAZANÇ² \\ ${ }^{1}$ Çankırı Karatekin Üniversitesi, Orman Fakültesi, Peyzaj Mimarlığı Bölümü,18200, Çankırı \\ ${ }^{2}$ *Bartın Üniversitesi, Bartın Orman Fakültesi, Orman Mühendisliği Bölümü,74100, Bartın
}

\begin{abstract}
Öz
Yaban hayvanları doğal yaşam ortamlarının farklı sebeplerden dolayı tahrip olması ile karşı karşıyadır. Bu tahribatların önemli sebeplerinden biri de karayollarıdır. Karayolları yaban hayvanlarının yaşam alanlarında habitat parçalanmalarına sebep oldukları gibi, yaban hayvanı araç çarpışmaları nedeni ile ölümlere de sebep olmaktadır. Mayıs 2014 ile Mayıs 2018 tarihleri arasında Kırıkkale-Çankırı karayolu üzerinde yaban hayvanları ile araç çarpışmalarını incelediğimiz bu çalışmada 9 türden 389 adet memeli yaban hayvanı kazası kaydedilmiştir. Çalışmada kirpi 182, tilki 136, sansar 44, yaban domuzu 12, kurt 6 , tavşan 5 , porsuk 2, arap tavşanı ve gelincik ise 1 adet olarak kazalara karışmıştır. Çalışma alanında 4 adedi yaban domuzu ve 6 adedi ise karaca figürlü olan toplam 10 adet yaban hayvanı uyarı levhası olduğu ve bu uyarı levhalarının kazaların 52 adedinin meydana geldiği noktalara yerleştirildiği ve tüm kazaların \%13,5'i kadarına etkili olduğu görülmüştür. Sonuç olarak Kırıkkale-Çankırı karayolunda bulunan yaban hayvanı uyarı levhalarının gerek konum gerekse de sayı olarak yeterli olmadığı belirlenmiştir.
\end{abstract}

Anahtar Kelimeler: Yaban hayvanı, araç, çarpışma, uyarı levhası, karayolu.

\section{Assessment of The Location of Wild Animal Warning Sign in Kırıkkale-Çankırı Highway}

\begin{abstract}
Wild animals face the destruction of their natural habitats for different reasons. One of the most important reasons for this destruction is the highways. Highways not only cause habitat fragmentation in the habitats of wild animals, but also cause deaths due to vehicle collisions. Between May 2014 and May 2018, in this study we examined collisions with wild animals on the Kırıkkale-Çankırı highway and 389 mammalian wildlife accidents of 9 species were recorded. In this study, hedgehog 182, fox 136, marten 44, wild boar 12, wolf 6 , rabbit 5 , badger 2, arabic rabbit and weasel 1 pieces were determined. In the study area, 4 wild boars and 6 deer-shaped wild animal warning signs were found and these warning signs occurred in 52 of the accidents and were effective up to $13.5 \%$ of all geese. As a result, it was determined that the wild animal warning signs on Kırıkkale-Çankırı highway were not sufficient both in terms of location and number.
\end{abstract}

Keywords: Wild animal, vehicle, collision, warning sign, highway. 


\section{Giriş}

Karayollarının da içinde bulunduğu ulaşım ağlarının yaban hayvanları üzerine başta habitat kaybı ve peyzaj parçalanması olmak üzere fiziksel etkileri yanında, gürültü kirliliği, görsel rahatsızlık, birey kaybı, insan etkisinin artması, yol kenarının işlev kazanması ve bariyer etkisi yaratması gibi birçok ekolojik etkileri de bulunmaktadır (Iuell vd., 2003). Yaban hayvanları bir habitattan diğer bir habitata geçerken veya yolun oluşturduğu koridoru beslenme amacıyla kullanırken ulaşım araçları tarafından ezilmek veya çarpılmak sureti ile ölmektedirler. Bu ölümler kimi zaman yaban hayvanlarının popülasyonları üzerinde önemli bir etkiye sahip olabilirler. Hatta bazı türler için bu tip ölümler popülasyonlarının azalmalarında oldukça yüksek bir paya sahiptir. Huijser vd. (2015) karayolları ve trafiğin ekolojik etkilerini; yaban hayatı yaşam alanlarının kaybı, yol ölümleri, bariyer etkisi, habitat kalitesinde azalma (rahatsızlık, kirlilik) ve kenarların ekolojik işlevi olarak belirtmiştir (Şekil 1).

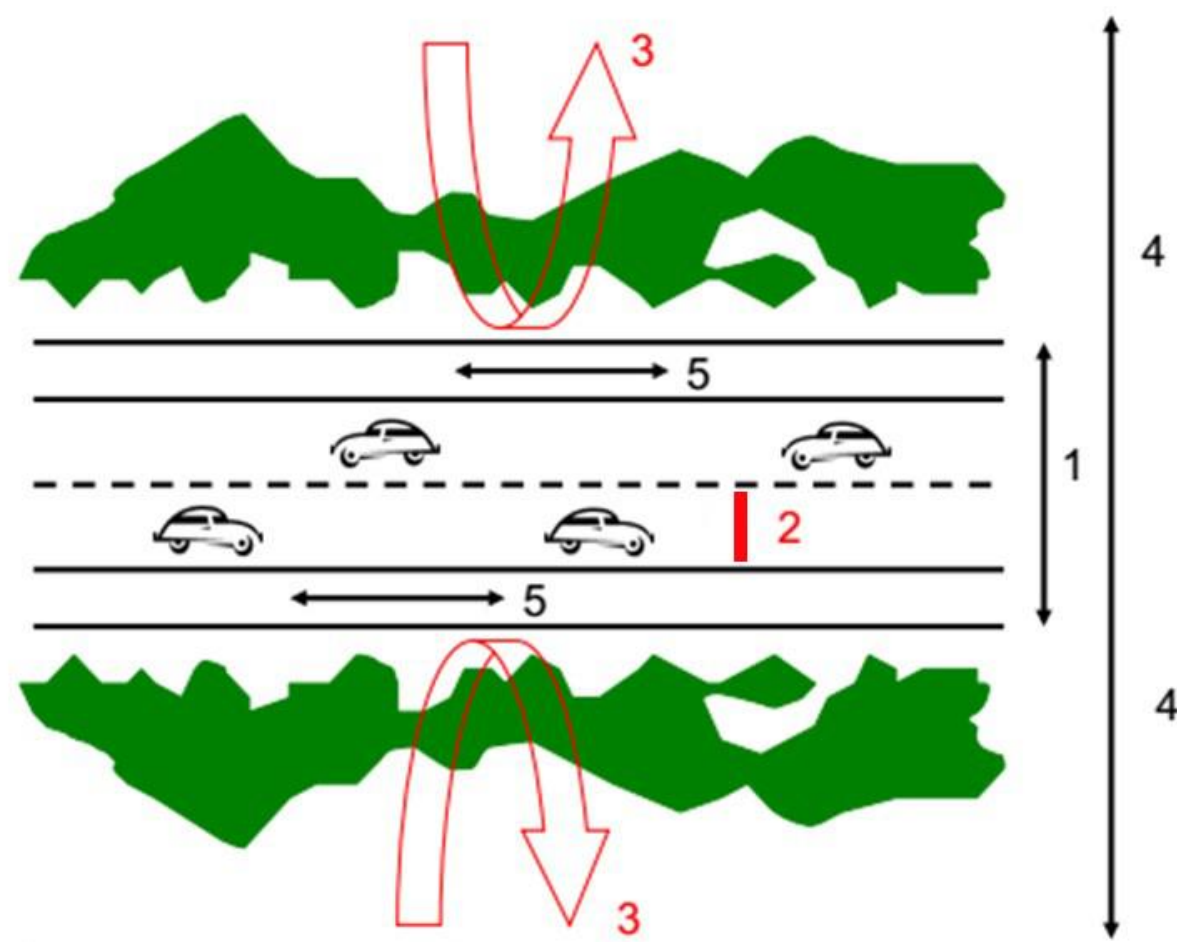

Şekil 1. Karayolları ve trafiğin yaban hayatına olan ekolojik etkileri. 1) yol sebebi ile yaban hayatı yaşam alanlarının tamamen yok olarak yaban hayatı alanı vasfinı yitiren kısım 2) yollar üzerinde en çok yaban hayvanları ölümlerinin olduğu alanlar 3) yol kenarı yapıları (duvar, heyelan kontrol, ağaçlandırma) sebebi ile yaban hayvanlarının geçişlerindebariyer etkisi meydana gelen alan 4) yolun mevcut yaban hayatı habitatının kalitesinde meydana getirdiği azalmabölgesi 5) yaban hayvanlarının yol kenarında gezindiği ekolojik işlev eşiği (Huijser vd. 2015).

Ekolojik olarak Yaban Hayvanı Araç Çarpışması (YHAÇ) yaban hayvanlarının popülasyon azalmasının bir göstergesidir (Lodé, 2000) ve farklı hayvan popülasyonlarını etkileyebilmektedir (Bissonette vd. 2008). YHAÇ'lerin yaban hayvanlarının popülasyonunu etkileme dereceleri belirlenirken bazı değerler göz önüne alınır.Eğer YHAÇ popülasyon ölümlerinin küçük bir kısmını oluşturuyorsa düşük derecede (Bruinderink ve Hazebroek 1996), YHAÇ ile meydana gelen ölüm miktarı avcılık aktiviteleri ile meydana gelen ölüm miktarına eşit ise orta derecede (Forman ve Alexander, 1998; Gosselink vd., 2007) YHAÇ ile ölen yaban hayvanlarının miktarı o türün popülasyonunutehdit edecek kadar fazla ise yüksek (Huijser ve Bergers, 2000; Kramer-Schadt vd., 2004) derecede olarak sınıflandırılmaktadır. Örneğin İspanya'da İber vaşağının en yüksek ikinci ölüm sebebi (Ferreras vd., 1992), Newyork’ta ise akkuyruklu geyiğin en yüksek üçüncü ölüm sebebini (Sarbello ve Jackson, 1985) bu kazalar oluşturmaktadır.

YHAÇ’lerin önemli derecede sosyal, ekonomik ve ekolojik sonuçları vardır. Sosyal olarak, YHAÇ’ler trafik ve insan güvenliğini tehdit ederek; yaralanmalara, travmalara ve kimi zamanda araç içindeki insanların ölümlerine sebep olabilir (Williams ve Wells 2005). Araç hasarları, yaralanma veya insan ölümleri ile sonuçlanan YHAÇ'ler çoğunlukla büyük yaban hayvanı türlerinin $(>30 \mathrm{~kg})$ karıştığı çarpışmalardan kaynaklanmaktadır (Barthelmess ve Brooks 2010; Ford ve Fahrig 2007). Bu tip kazalar araçlarda meydana gelen hasarlar nedeniyle yüksek bir ekonomik etkiye de sahiptir. 
Conover vd. (1995) ve Romin ve Bissonette (1996) ABD'de YHAÇ sonucunda yılda 200 kişinin öldüğü, 29.000 kişinin yaralandığını ve 1 milyar dolar maddi zarar meydana geldiğini bildirmiştir. Bissonette vd. (2008) Utah'da 1996-2001 yılları arasında gerçekleşen yaklaşık 13.000 YHAÇ’yi incelemişler ve ortalama kaza başına 3.470 dolar maliyet oluştuğunu yazmışlardır. Bu kazalardaki maliyetin \%53'ünü ölüm sigortası, \%18'ini araç hasarı, \%6'sını yaban hayvanı kaybı ve \%1'ini ise insan sakatlı̆̆ı oluşturmaktadır. Gilbert vd. (2017) YHAÇ'lerin \%22'sinin gerçekleştiği Batı ABD'de son otuz yılda 155 kişinin öldüğünü 21.400 kişinin yaralandığını ve 2.13 milyar dolar maddi zarar meydana geldiğini belirtmiştir. Avrupa ülkelerinde de YHAÇ sonucunda önemli derecede zararlar meydana gelmektedir. Saenz-de-Santa-Marea ve Telleria (2015) İspanya'da 2006-2012 yılları arasında kayıt altına alınan 74.600 YHAÇ'de yıllık 105 milyon Euro zararın meydana geldiğini, kazalardaki ekonomik kayıpların \%43’ünü yaban domuzu ve \%31'ini karaca sebebiyle oluştuğunu bildirmiştir. Fransa'da ise bu maliyet, 2003 yılı için yaban hayatının zarara uğramasının maliyetinden beş kat daha fazla 200 milyon Euro olarak değerlendirilmiştir (Vignon ve Barbarreau 2008). Türkiye'de ise resmi kurumlar tarafından YHAÇ sonucu ortaya çıkan kazaların maddi ve hayati boyutu üzerinde yayınlanmış her hangi bir veri bulunmamaktadır.

Ulaşım ağalarında meydana gelen bu tip YHAÇ’leri önlemede en etkin yollardan birisi de hiç kuşkusuz ki Yaban Hayvanı Uyarı Levhasıdır (YHUL). YHUL, yollar üzerinde yaban hayvanlarının potansiyel veya fiili varlığı hakkında sürücüleri uyararak yaban hayvanı araç çarpışmalarını azaltmayı amaçlamaktadır (Huijser vd., 2015). Bu levhalar haricinde YHAÇ’leri azaltmaya yönelik olarak yapılan çitler, yeşil köprüler ve elektrik uyarı levhaları gibi farklı önlemlerin yapımı ve bakımı genellikle maliyetlidir (Kruidering vd., 2005; Huijser v.d., 2007). Bunun yanında; koku alma kovucuları, YHUL, hız sınırı azaltma uygulamaları, insanları uyarmaya yönelik özel eğitimler gibi tedbirler daha az maliyetli olsa da bunların uzun vadede etkisiz olduğu görülmüştür (Elmeros vd., 2011; Beben, 2012).

Günümüzde YHAÇ önlemede en çok kullanılan tekniklerden biri olan YHUL 1960 yıllardan sonra geliştirilmeye başlanmış ve 1964 yılında çok amaçlı yollar için trafik işaretleri raporu olarak bilinen Wortboys raporunda dile getirilmiştir. Daha önce siyah beyaz basit bir yazı olan bu levhalar zamanla geliştirilerek renkli levhalara dönüştürülmüştür. İlk zamanlar genel yaban hayvanı uyarı niteliğinde koşan bir karaca ile resmedilen bu levhalar ilerleyen zamanda ve gelişen ekosistem bilincinde türlere özel levhalar haline dönüşmüştür (URL$01)$.

Günümüzde farklı yaban hayatı alanları ve türleri için birkaç farklı YHUL vardır. Bu levhalar sürücülere, sıklıkla karayolundan yaban hayvanlarının geçtiği bilinen bir alana yaklaşmakta olduklarını belirtmektedir. Farklı ülkelerde farklı renk ve boyutlarda olan bu levhaların amaçları aynıdır (URL-02).

Bond ve Jones (2013) YHUL ve bunların sürücülerdeki algıları üzerine yaptıkları bir çalışmada; mevcut levhaların etkinliğinin az olduğu ve çoğunlukla bu levhalara bağlı olarak sürücü davranışlarında çok az bir değişiklik olduğunu belirterek, sürücülerin bu levhalara tepkisini arttırmak için bunların tasarımının iyileştirilmesi ile YHAÇ'lerin azaltılma potansiyelinin olduğunu bildirmişlerdir. Araştırmada Avustralya'da mevcut üç levha tasarımı ile beş yeni alternatif levha tasarımı karşılaştırılmıştır. Sürücülerin sekiz levhaya verdikleri tepkiler üç hız limitinde ayrı ayrı ölçeklendirilmiş ve en çok tepki alan levhalar belirlenmiştir. Sonuçta hareketli hayvan figürü ve araç hız sınırı olan levhalar sürücüler tarafindan çok daha fazla dikkate alınmıştır.

Dünyanın birçok ülkesinde özellikle de yaban hayatı alanlarında YHUL'ler kanunlar, yönetmelikler ve saha çalışmaları ile yerleri belirlenerek dikilmektedir. Türkiye'de ise YHUL'ler için konu ile ilgisi olan "Trafik İşaretleri Hakkında Yönetmelik", "Karayolu Trafik Güvenliğinin Sağlanması Yönünden, Yolun Yapısında Yapılacak Her Türlü Çalışmalarda Alınacak Tedbirler İle Karayolu Dışında, Kenarında veya Üzerindeki Diğer Levhalar, Işıklar ve İşaretlemeler Hakkında Yönetmelik" ve "Yaban Hayatı Koruma ve Yaban Hayati Geliştirme Sahaları İle İlgili Yönetmelik” de dahil olmak üzere hiç birinde özel bir madde ya da açıklama yoktur.

Bu kapsamda yapmış olduğumuz çalışma ile Kırıkkale-Çankırı karayolu üzerindeki YHUL'lerin mevcut durumlarının belirlenerek YHAÇ'ler ile arasındaki bağların kurularak bu levhaların doğruluğu analiz edilmiş, karayollarında YHUL'lerinkullanımı için öneriler getirilmiştir. 


\section{Materyal ve Metot}

\subsection{Materyal}

Çalışmanın ana materyalini Kırıkkale-Çankırı Karayolu'nun 90 km.'lik kısmında bulunan yaban hayvanı uyarı levhaları ile bu kısımda meydana gelen yaban araç çarpışmaları oluşturmuştur. Çalışmada YHAÇ’leri kaydetmek için el GPS, kayıtları belgelemek için dijital fotoğraf makinesi, örneklerin alınması ve verilerin toplanması amacı ile not defteri kullanılmıştır.

\subsection{Metot}

Çalışma iki aşamada gerçekleştirilmiştir. İl aşamada Kırıkkale-Çankırı Karayolu'nda trafik kazası sonucu ölen yaban hayvanları kaydedilmiş, aynı zamanda yol üzerindeki yaban hayvanı uyarı levhalarının konumları ve mevkileri belirlenmiştir. Mayıs 2014 ile Mayıs 2018 tarihleri arasında yürütülen çalışmada YHAÇ'leri tespit etmek amacı ile haftada en az bir gün olacak şekilde sabah en geç 06.00 da yola çıkılarak örnekler toplanmıştır. Yol boyunca ortalama $50 \mathrm{~km} / \mathrm{sa}$ hızla gidilerek tüm YHAÇ kalıntıları incelenmiştir. Kayıtlar alındıktan sonra çift sayımları engellemek için çarpılma kalıntıları yolun kenarına çıkarılmış ve yaban hayvanı ölülerinin bulunduğu noktaların koordinatları (UTM) 5 metre hassasiyete sahip GPS aracılığıyla alınmıştır. Trafik yoğunluğunun fazla olduğu durumlarda tehlikeli bir durumun ortaya çıkmaması için bu işlemler yol kenarından gerçekleştirilmiştir. Çarpışmanın olduğu noktadan yolun durumu ve özelliklerini belirlemek amacı ile 45 derecelik açı ile sekiz adet fotoğraf ve çarpmanın olduğu yönde yaklaşık 50 metre mesafeden ise 1 fotoğraf çekilmiştir. Kayıtlar sırasında ölen yaban hayvanın türü, tarih, km, konum gibi bazı veriler not edilmiştir (Şekil 2).
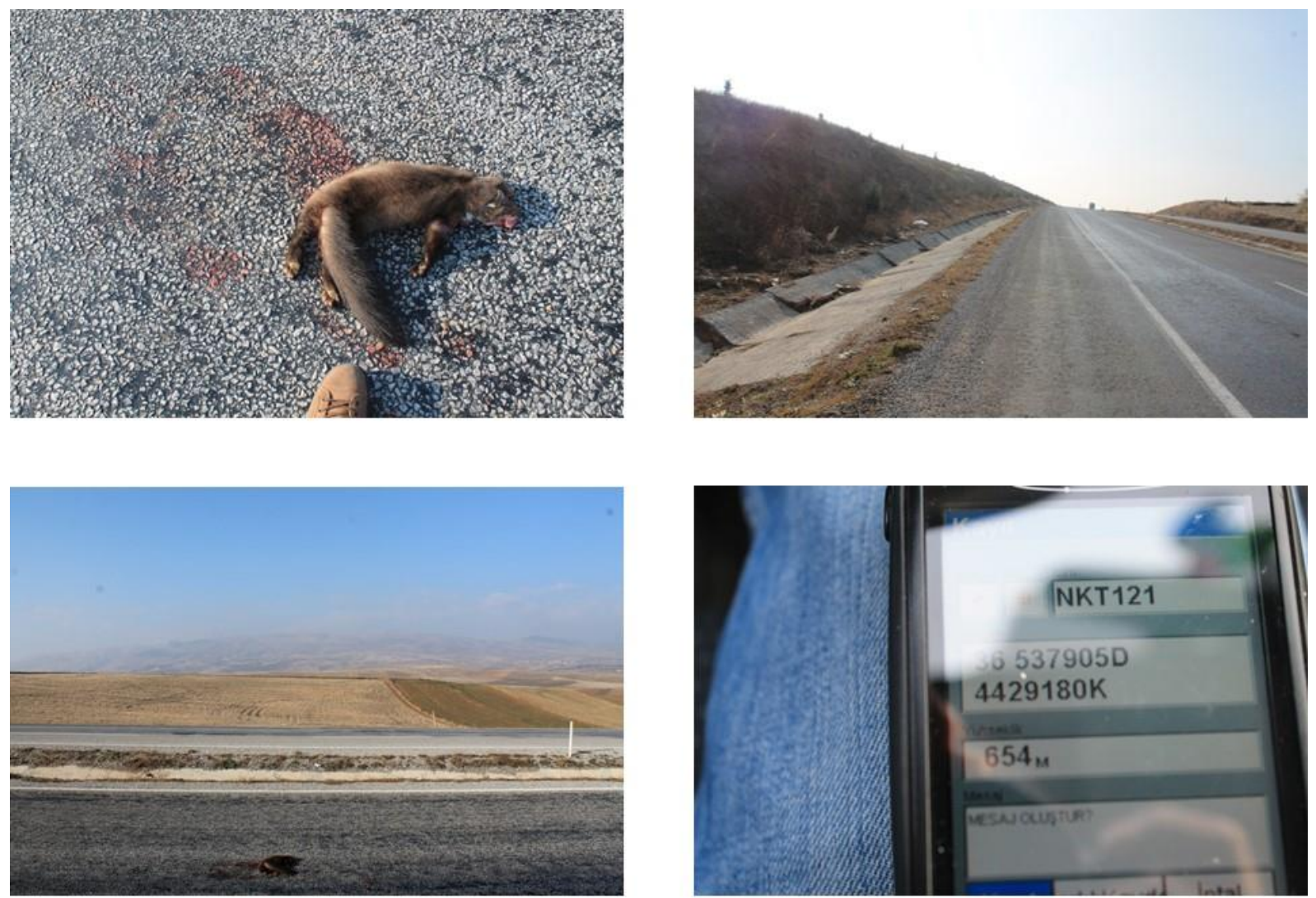

Şekil 2: Karayolunda ölen yaban hayvanlarının veri kayıtlarının yapılması (sansarı).

Çalışmanın ikinci aşamasında YHAÇ ile YHUL arasındaki bağıntılar incelerek ilişkilendirilmiş ve sonuçta bu alan özelinde YHUL'lerin konumları ve özellikleri irdelenerek genel anlamda YHUL'lerin kullanımı hakkında öneriler verilmiştir.

\section{3. Çalışma Alanı}

Çalışma alanı Kırıkkale-Çankırı 765 nolu (05-06-07) Karayolu’nun yaklaşık olarak 90 km. uzunluğundaki bir 
bölümünü kapsamaktadır (Şekil 3). Yol hattının bulunduğu arazi engebeli bir topografya oluşturmakta olup 650-950 m arasında rakıma sahiptir. Peyzaj genel itibari ile antropojenik (insan etkisi) etkilere maruz kalmış olup, yolun her iki tarafında da yoğun miktarda tarım alanı mevcuttur. Yol boyunca yer yer meralar bulunmakta, yol Tüney çayı ve Tatlıçay akarsuları ile paralellik göstermektedir. Karayolunda hız sınırı otomobiller için $110 \mathrm{~km} / \mathrm{sa}$; kamyon, otobüs ve tırlar için $90 \mathrm{~km} / \mathrm{sa}$ 'dir. Karayolları Genel Müdürlüğü ölçümlerine göre yol düşük ve orta yoğunlukta olmak üzere iki bölümden oluşmaktadır. Yolun her iki yanında toplamda 10 adet yaban hayvanı uyarı levhası bulunmaktadır.

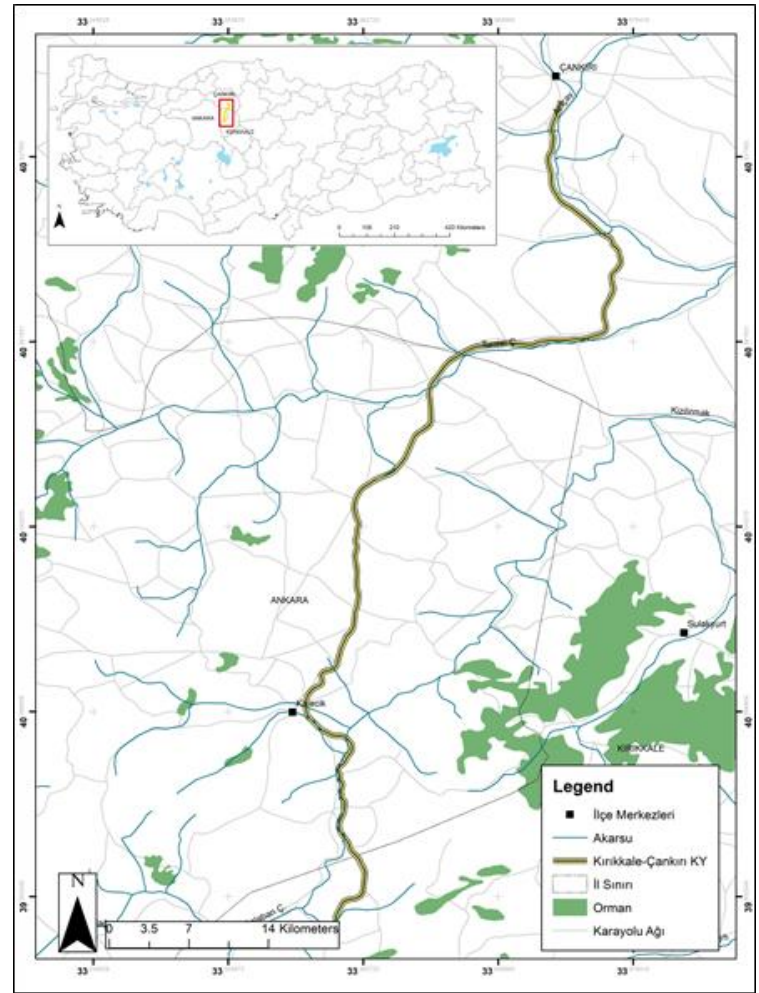

Şekil 3: Çalışma alanı olan Kırıkkale-Çankırı karayolu.

\section{Bulgular}

Çalışma süresi boyunca sahada YHAÇ sonucunda ölen 9 türden 389 adet memeli yaban hayvanı kaydedilmiştir (Tablo 1).

Tablo 1: Kırıkkale-Çankırı Karayolu'nda çalışma süresince araç çarpması sonucu ölen yaban hayvanları.

\begin{tabular}{lcccccc}
\hline & \multicolumn{2}{c}{ Orta trafik hacmi } & \multicolumn{2}{c}{ Düşük trafik hacmi } & \multicolumn{2}{c}{ Toplam } \\
\cline { 2 - 6 } & Adet & \% & Adet & \% & Adet & \% \\
\hline Arap Tavşanı & 1 & 0.26 & 0 & 0.00 & 1 & 0.26 \\
Yaban domuzu & 10 & 2.57 & 2 & 0.51 & 12 & 3.08 \\
Gelincik & 1 & 0.26 & 0 & 0.00 & 1 & 0.26 \\
Kirpi & 110 & 28.28 & 72 & 18.51 & 182 & 46.79 \\
Kurt & 6 & 1.54 & 0 & 0.00 & 6 & 1.54 \\
Porsuk & 2 & 0.51 & 0 & 0.00 & 2 & 0.51 \\
Sansar & 41 & 10.54 & 3 & 0.77 & 44 & 11.31 \\
Tavşan & 5 & 1.29 & 0 & 0.00 & 5 & 1.29 \\
Tilki & 121 & 31.11 & 15 & 3.86 & 136 & 34.96 \\
\hline Toplam & 297 & 76.35 & 92 & 23.65 & 389 & 100.00 \\
\hline
\end{tabular}

Tablo 1'dende görüldüğü üzere kazalarda en fazla ölen yaban hayvanı 182 adet ile kirpi (Erinaceusconcolor)'de olmuştur. Bunu sırasıyla tilki (Vulpesvulpes) 136 adet, sansar (Martes sp.) 44 adet, yaban domuzu (Susscrofa) 12 adet, kurt (Canislupus) 6 adet, tavşan (Lepuseuropaeus) 5 adet, porsuk (Melesmeles) 2 adet, arap tavşanı 
(Allactagawilliamsi) 1 adet ve gelincik (Mustelanivalis) 1 adet olarak takip etmiştir.

YHAÇ sonucu ölen yaban hayvanlarının $10 \mathrm{~km}$ 'lik yol bölümlerine göre dağılımları ise Tablo 2'de görülmektedir. Buna göre kirpi ve tilkilere yolun bütün bölümlerinde araç çarpmışken, yolun 50-60. km'lerinde 7 türün karıştığ 67 adet ölümcül kaza tespit edilmiş ve bu kısım en çok kazanın gerçekleştiği bölüm olmuştur. En az kaza ise 3 türün karıştığı ve toplamda 14 kaza tespit edilen yolun $0-10 . \mathrm{km}$ arasında kalan bölümünde meydana gelmiştir.

Tablo 2: Kırıkkale-Çankırı Karayolu'nda çalışma süresince araç çarpması sonucu ölen yaban hayvanların 10 km'lik bölümlere dağılımı ve yol ölüm oranları (adet/100 km/yıl).

\begin{tabular}{|c|c|c|c|c|c|c|c|c|c|c|c|c|c|c|c|c|c|c|c|}
\hline \multirow{3}{*}{ Tür } & \multicolumn{16}{|c|}{ Yol bölümü (km) } & & & \\
\hline & \multicolumn{2}{|c|}{$0-10$} & \multicolumn{2}{|c|}{$20-30$} & \multicolumn{2}{|c|}{$20-30$} & \multicolumn{2}{|c|}{$30-40$} & \multicolumn{2}{|c|}{$40-50$} & \multicolumn{2}{|c|}{$50-60$} & \multicolumn{2}{|c|}{$60-70$} & \multicolumn{2}{|c|}{$70-80$} & \multicolumn{2}{|c|}{$80-90$} & \multirow{2}{*}{ Toplam } \\
\hline & $\mathbf{N}$ & $\%$ & $\mathbf{N}$ & $\%$ & $\mathbf{N}$ & $\%$ & $\mathbf{N}$ & $\%$ & $\mathbf{N}$ & $\%$ & $\mathbf{N}$ & $\%$ & $\mathbf{N}$ & $\%$ & $\mathbf{N}$ & $\%$ & $\mathbf{N}$ & $\%$ & \\
\hline Arap Tavşanı & & & & & & & & & & & 1 & 2,5 & & & & & & & 1 \\
\hline Yaban domuzu & 2 & 5 & 1 & 2 , & 1 & 2,5 & 5 & 12,5 & & & 0 & & 2 & 5 & 1 & 2,5 & 0 & & 12 \\
\hline Gelincik & & & & & & & 1 & 2,5 & & & & & & & & & & & 1 \\
\hline Kirpi & 9 & 22 & 26 & 6 & 3 & 97,5 & 23 & 57,5 & 17 & 42,5 & 25 & 62,5 & 26 & 65 & 9 & 22,5 & 8 & 20 & 182 \\
\hline Kurt & & & & & & & 2 & 5 & 1 & 2,5 & 3 & 7,5 & & & & & & & 6 \\
\hline Porsuk & & & & & & & 1 & 2,5 & & & 1 & 2,5 & & & & & & & 2 \\
\hline Sansar & & & 3 & 7, & & & 7 & 17,5 & 10 & 25 & 15 & 37,5 & 6 & 15 & & & 3 & 7,5 & 44 \\
\hline Tavşan & & & & & & & & & 1 & 2,5 & 2 & 5 & 2 & 5 & & & & & 5 \\
\hline Tilki & 3 & 7,5 & 6 & 1 & 9 & 22,5 & 23 & 57,5 & 20 & 50 & 20 & 50 & 26 & 65 & 16 & 40 & 13 & 32,5 & 136 \\
\hline Toplam & 14 & 35 & 36 & 9 & 4 & 122,5 & 62 & 155 & 49 & 122,5 & 67 & 167,5 & 62 & 155 & 26 & 65 & 24 & 60 & 389 \\
\hline
\end{tabular}

Yapılan gözlemlerde Kırıkkale-Çankırı Karayolu üzerinde toplam 10 adet YHUL olduğu belirlenmiştir. Bunlardan 4 adeti Kırıkkale-Çankırı istikametinde kalan 6 adeti ise Çankırı-Kırıkkale istikameti üzerinde yer almaktadır. Bu levhalarının 6 adedi KGM tarafından genel olarak kullanılan karacafigürlü ve 4 adedi ise yaban domuzu figürlü YHUL'dir (Şekil 4). Levhalar üçgen şeklinde, kırmızı şeritli ve beyaz fon üzerine siyah hareketli hayvan figürü ile tasvir edilmiştir. Yaban domuzu figürlü ikaz levhalarının üstünde 70 km'lik hız sınırı işareti bulunmaktadır, karacafigürlü ikaz levhalarında ise herhangi bir hız sınırı işareti yoktur. Bir ikaz levhası hariç diğer ikaz levhaları yolun iki yanında karşılıklı olarak bir koridor oluşturacak şekilde yerleştirilmiş̧tir. Yaban domuzu figürlü ikaz levhaları Kırıkkale-Çankırı Karayolu'nun 36.8, 37.8, 39.2, 39.6. km'lerinde, karacafigürlü ikaz levhaları ise yolun 52.8, 54.8, 66.6, 67.1, 76.5 ve 78.0. km'lerinde yer almaktadır (Şekil 5).

Yaban domuzu figürlü levhalarının bulunduğu alanlar (Şekil 6.a) yaklaşık olarak 1000 metre (36.8-37.8 km'ler arası) ve 400 m.' lik (39.2-39.6 km'ler arası) alanlarda uyarı yapmaktadır. 39.2-39.6 km'ler arasındaki levhalar alanda en fazla yaban domuzu çarpışmasının meydana geldiği bölgeyi oluşturmaktadır. Bu iki levha arasında 4 adet YHAÇ meydana gelmiştir. Bu 4 çarpışmadan ise sadece iki tanesi ikaz levhalarının arasında diğerleri ise levhalara çok yakın noktalarda meydana gelmiştir. 36.8-37.8 km’ler arasındaki yaban domuzu figürlü levhalar arasında ise hiçbir yaban domuzu kazası kaydedilmemiştir. Ancak 37.8. km'deki levhanın yaklaşık olarak 250 metre ilerisinde 1 adet yaban domuzu kazası meydana gelmiştir. Bunlara ilaveten 36.8-37.8 km'lerdeki levhalar arasında 1 er adet kirpi, kurt ve tilki; 39.2-39.6 km'lerdeki levhalar arasında ise 2 adet sansar ile 1 adet porsuk kazası kaydedilmiştir. Ayrıca her iki levha grubu arasında yer alan (37.8-39.2 km'ler arası) 1,4 km'lik alanda ise 4 adet tilki ile 2 adet kirpi kazası kayıtlanmıştır.

Karayolunun Kırıkkale-Çankırı istikametindeki 52.8-54.8 km’leri arasındaki (Şekil 6b.) karaca figürlü ikaz levhaları arasında 4 adet kirpi, 1 adet arap tavşanı, 3 adet sansar, 2 adet tilki ve 2 adet kurt olmak üzere toplamda 12 adet kaza kayıtlanmıştır. Ancak 52.8. km'deki levhanın yaklaşık $350 \mathrm{~m}$ ön ve arkasında kalan yol bölümünde hiç kaza kaydı yok iken 54.8. km’deki levhanın 150-200 m. ön ve arka kısmında yoğun bir kaza birikimi olduğu göze çarpmaktadır. Bu kısımda levhadan önce 6 adet ve levhadan sonra ise 7 adet kaza kaydı alınmıştır. Yolun 500 metrelik bir alanında uyarı yapmakta olan 66.6 ve 67.1 . km'deki karaca figürlü ikaz levhaları arasında 2 adedi tilki kalanı ise kirpi olmak üzere 10 adet kaza sayılmıştır (Şekil 6c). Bu bölümdeki kazalar çoklukla $67.1 \mathrm{~km}$ 'deki levha çevresinde yoğunlaşmaktadır. 76.5-78.0. km'lerdeki 1,5 km'lik alanı gösteren son ikaz levhası çifti arasında ise hiçbir kaza kayıt altına alınmamıştır (Şekil 6d.). Fakat 76,5. km'deki levhadan önceki yaklaşık 1,5 km. ve 78,8. km'deki levhadan sonraki $1 \mathrm{~km}$.'lik yol boyunca kazaların orta yoğunlukta oldukları görülmektedir. 

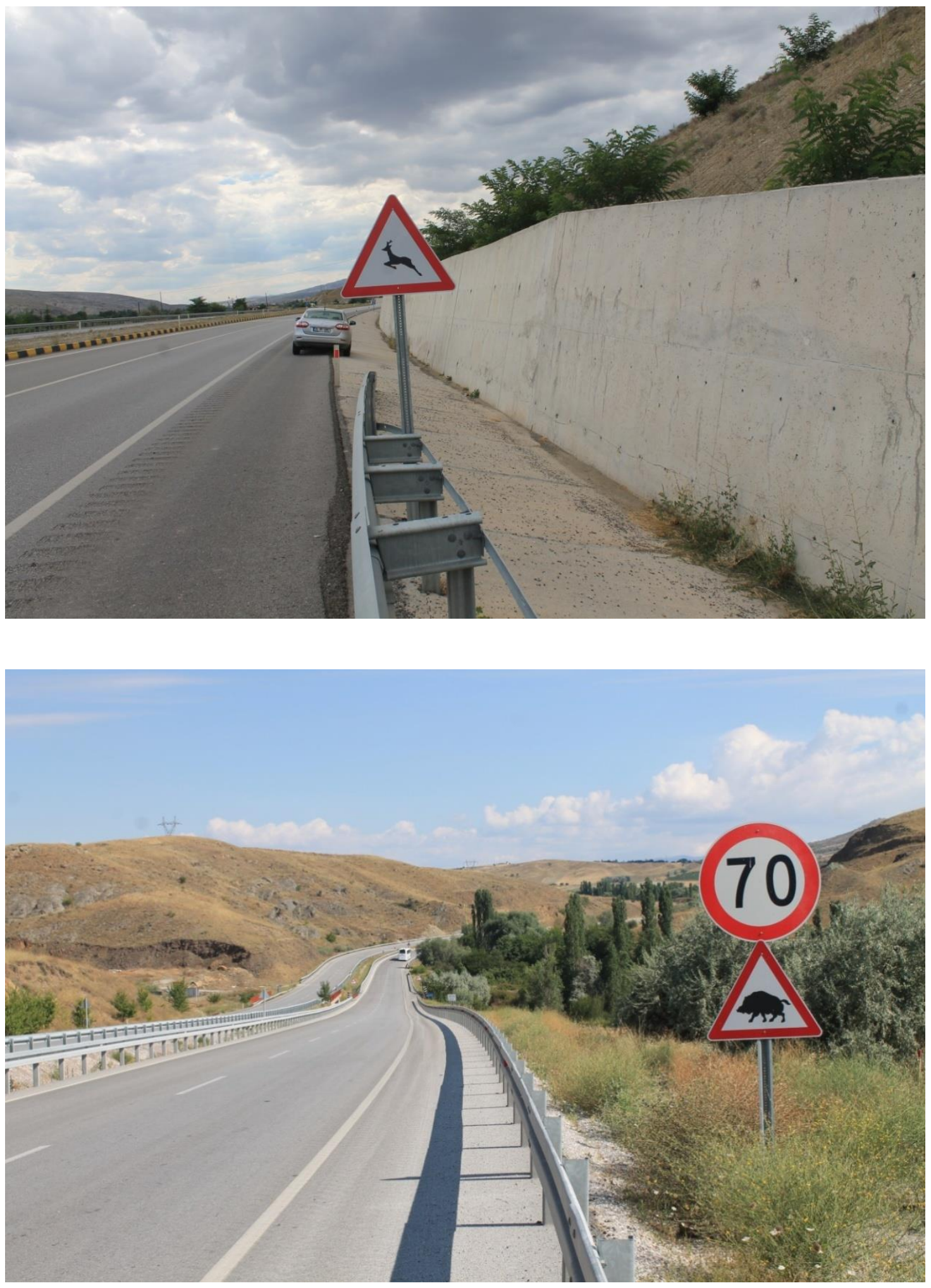

Şekil 4: Karaca (Karaşı köy) ve yaban domuzu (Çandır köyü) figürlüYHUL'leri. 


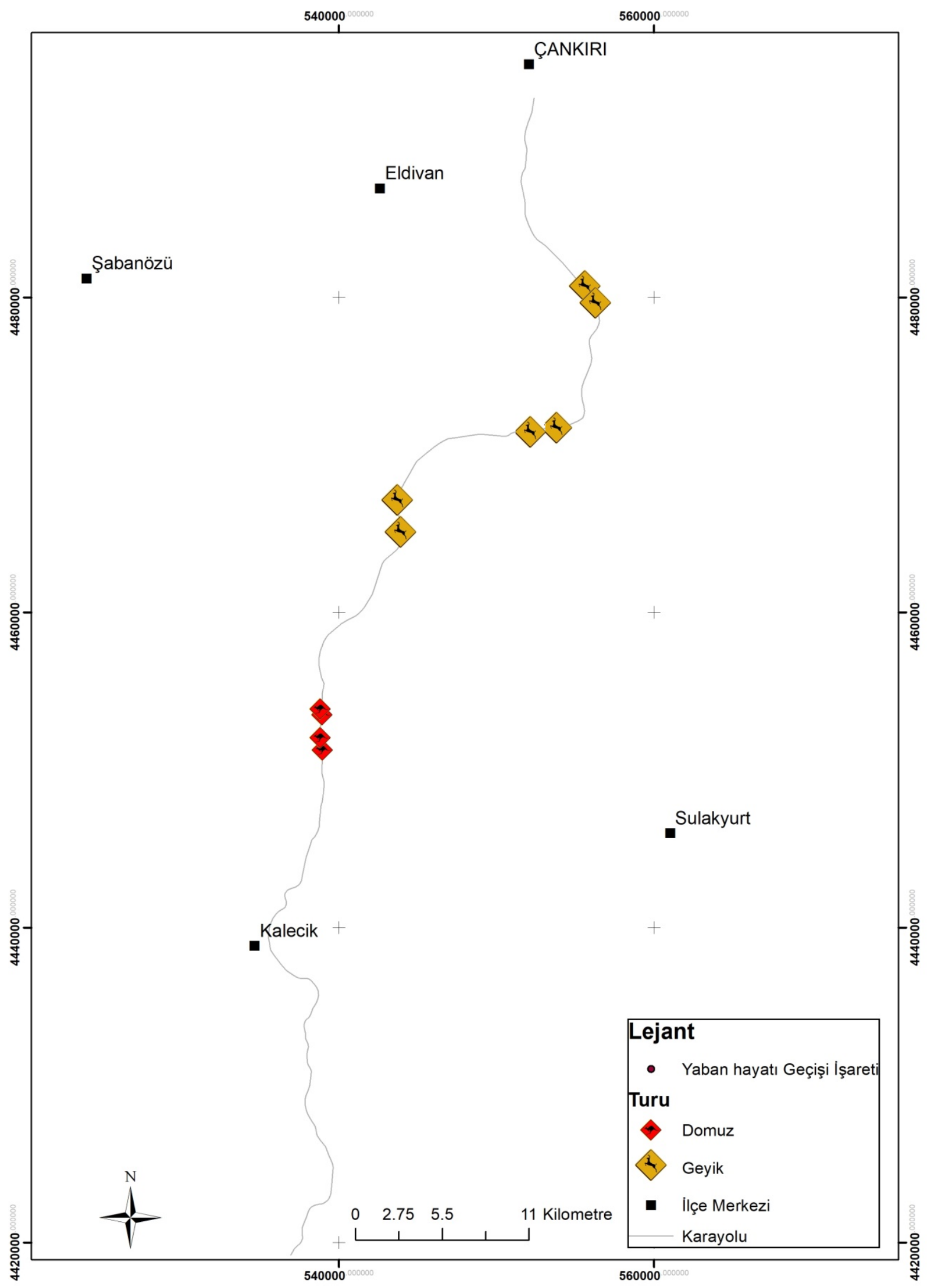

Şekil 5. Kırıkkale-Çankırı karayolu üzerindeki YHUL'lerin konumları. 


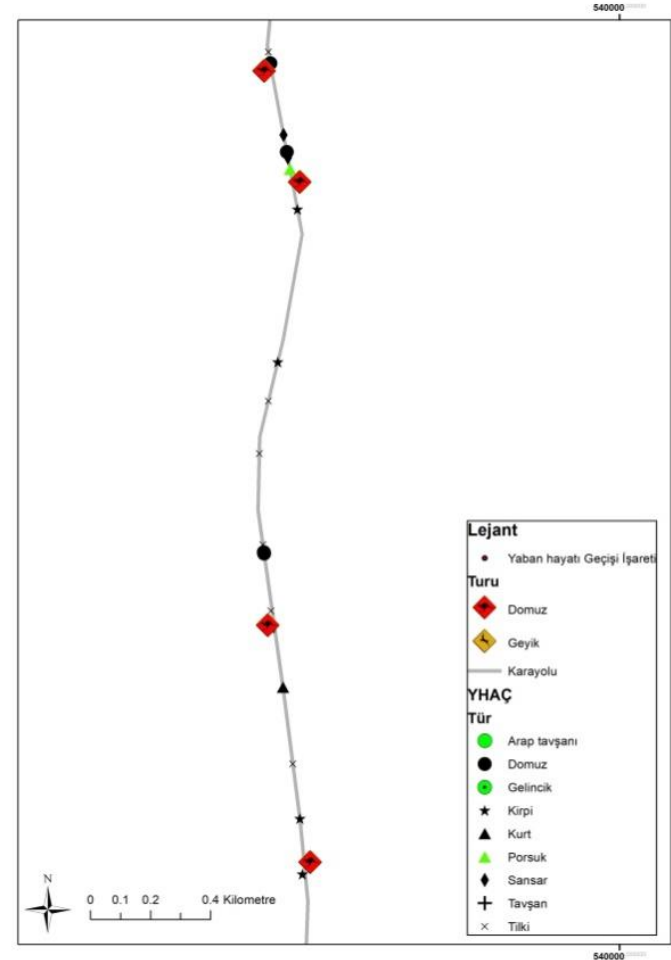

a

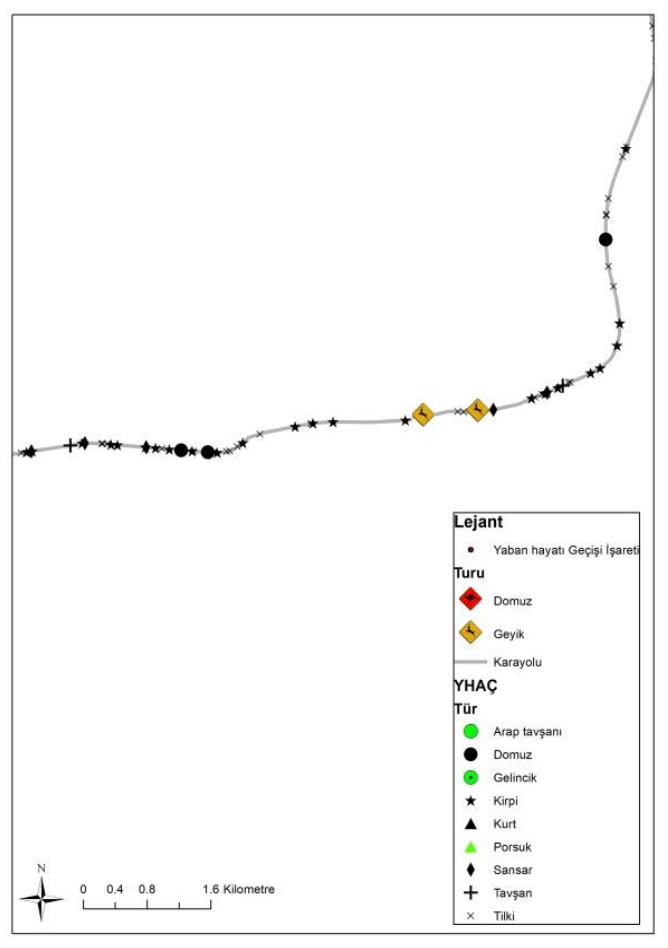

c

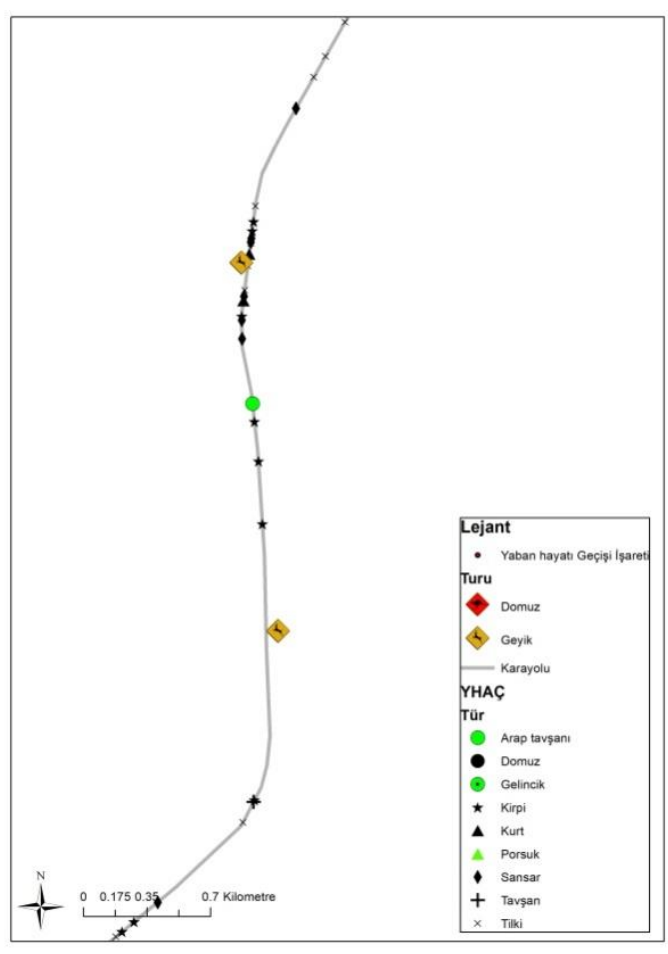

b

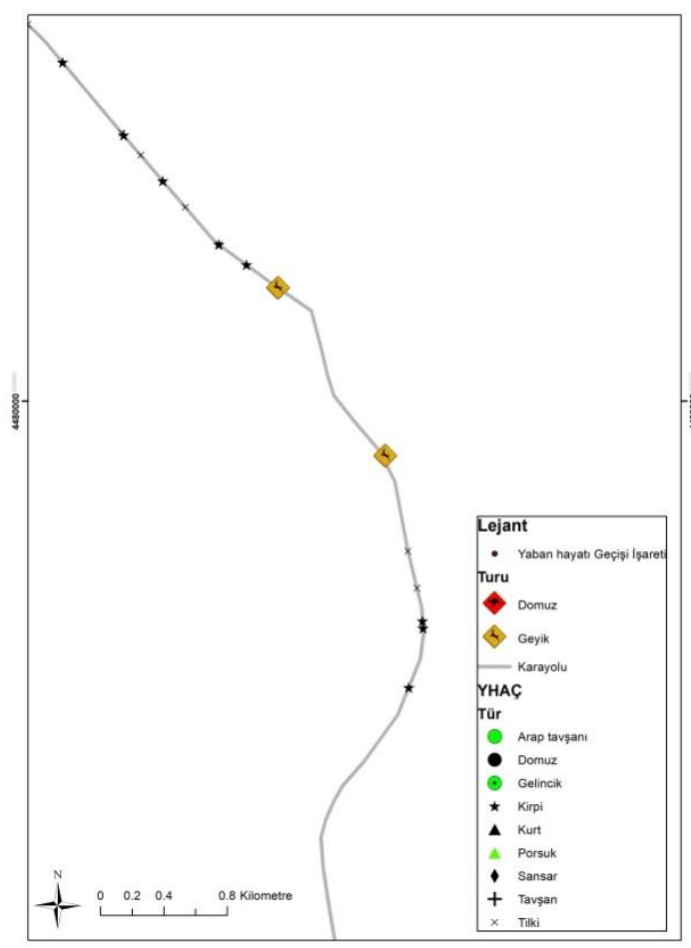

d

Şekil 6. Kırıkkale-Çankırı karayolu üzerindeki YHUL ve YHAÇ’lerin konumları. 


\section{Tartışma ve Sonuç}

Williams ve Wells (2005), Barthelmess ve Brooks (2010) ile Ford ve Fahrig (2007)'inde bildirdiği üzere yaban hayatı araç çarpışmaları sonucunda meydana gelen maddi hasarlar yanında insanlarda oluşan travmalar ve ölümler telafisi mümkün olmayan kayıplar olarak karşımıza çıkmaktadır. Özellikle büyük memeli yaban hayvanlarının karıștığı kazalarda bu tip sonuçlara daha çok rastlanmaktadır. Bu durum ekosistem ya da yaban hayatı yanında insanların sosyal yaşamına da zarar vermektedir. Bunun sonucunda bazı durumlarda yaban hayatına karşı negatif yönde bir yaklaşım da söz konusu olmaktadır. Bu bağlamda yapmış olduğumuz çalışmalar sonucunda Kırıkkale-Çankırı Karayolu'nda tespit ettiğimiz on iki adet yaban domuzu kazasından sadece bir tanesi yaralamalı kaza olmuş ve jandarma tarafindan rapor tutulmuştur. Yine yaban domuzu kazalarından üç tanesinde araçlarda maddi hasar oluşmuş, jandarma olay yerine gitmiş fakat araçlarda kasko trafik sigortası olmadığı için herhangi bir yasal işlem yapılmamıştır. Türkiye'de YHAÇ’ler ile ilgili olarak en önemli sorunlardan birisi sigorta şirketleri, KGM, Polis/Jandarma, DKMGM gibi konunun taraflarının YHAÇ sonucu ne kadar kişinin öldüğü, yaralandığı, sakat kaldığı, ne kadar maddi hasar meydana geldiği gibi bilgileri paylaşmaması ve bilinen bir kayıt ya da istatistik yöntem uygulamamasıdır. Bu sebepten dolayı YHAÇ'lerin ne maddi boyutu ne de bölgesel ve alansal yoğunlukları hakkında resmi bir bilgi ve veri kaydı yoktur. Çalışma süresi boyunca 4 yıl alanda kısıtlı bir veri kaydı alınsa da elimizdeki veriler ile ancak bu alandaki yaban hayvanı türlerinin kazaya karışma oranları ile olası kör noktalar tespit edilebilmesi ve bunların YHUL'ler ile ilişkilendirilmesi yapılabilmiştir. Çalışmalar sonucunda popülasyon yoğunlukları diğer türlere göre daha düşük olan kurt, porsuk ve gelincik için bu bölgedeki YHAÇ’lerin yüksek dereceli bir tehdit olduğu söylenebilir.

Yaban hayvanları günlük faaliyetleri kapsamında besin, barınak, su ve üreme faaliyetleri sebebi ile habitatlar arasında geçiş yaparlar ve aynı anda birkaç habitatı birden kullanma ihtiyacı duyarlar. Türlere göre değişiklik göstermekle birlikte yaban hayvanları günlük aktivitelerinde beslenmek için açık alanlar ve tarım alanları, su ihtiyaçları için akarsu ve göl habitatları, barınmak için orman ve kayalık alanları kullanabilmektedir. Bu sebepten karayolları ile tek bir habitat türünün parçalanmasından ziyade tüm ekosistemi birlikte irdelemek ve habitat parçalanması yerine ekosistem parçalanması yaklaşımını kullanmak daha doğru olacaktır. Karayolları sadece aynı habitatı değil yaban hayvanının kullandığı birçok farklı habitatı da ayırmaktadır. Bu yüzden ekosistem planlamalarında yaban hayvanlarının habitat ihtiyaçlarının tam olarak ortaya konulması gerekmektedir.

Karayolları konusunda çalışan ekoloji uzmanları YHAÇ’lerde risk etkenlerine karar vermekte peyzajla ilişkili karakteristiklere, hayvan dağılımının etkisine, bolluğuna ve yol çevresindeki habitatların dağılımının ne olduğuna ve bunun yanında bu yolla ilişkili trafik yoğunluğu, yol ve yol kenarı topografyasına göre istatistiki modeller kullanmaktadır (Joyce ve Mahoney, 2001; Clevenger vd., 2003; Malo vd., 2004; Dussoult vd., 2006; Jaarisma vd., 2007). Bu bilgiler; yaban hayatı için; üst geçitlerin, alt geçitlerin, bariyerlerin yapılmasında, dönemsel YHUL, hız azaltıcı yaban hayatı reflektörleri, yol kenarı yaban hayatı yönetimi, hız tümsekleri gibi önlemlerin alınmasında rehber olarak kullanılabilmektedir.

Tüm dünyada olduğu gibi ülkemizde de karayolları üzerinde meydana gelen YHAÇ’lerin boyutunun belirlenmesi, yaban hayatı üzerindeki ölümlerin ve diğer ekolojik etkilerin azaltılmasında ihtiyaç duyulan bir konudur. Fakat bir karayolunun tamamında bu etkilerin yönetilmesi hem ekonomik hem de lojistik olarak mümkün olmayacağı gibi ekolojik olarak da uygun değildir. YHAÇ azaltılması ve yaban hayatı geçişlerinin güvenli bir şekilde sağlanması için doğru yerde doğru önlemlerin alınması ekonomik ve ekolojik açıdan birçok fayda sağlayacaktır. Bu sebepten dolayı bu tip çalışmaların sonuçları ile YHAÇ için en uygun potansiyel noktaların belirlenmesi ve önlemlerin alınması ülke ekonomisine ve biyolojik çeşitliliğine önemli katkılar sağlayabilecektir.

Karayolları üzerine YHAÇ'lerin boyutunun belirlenmesi insanlarda meydana gelecek olan mal ve can kayıplarının yanında, yaban hayvanlarının ölümleri ve yaban hayatı üzerine dolaylı etkilerin azaltılmasında oldukça büyük bir etkendir. Örneğin Florida'da yol ölümlerinin yoğun konumsal analizlerini yapan Smith (1999, 2003) planlamanın nerede ve nasıl bir dizayn ile yapılacağını YHAÇ’lerin hayvan hareketleri, dağılımı, peyzaj deseni ve yol ölümlerinin lokasyonu göz önünde bulundurarak hafifleteceğini önermiştir. Ayrıca, trafik kazaları ile toplanan bilgiler kazaların azaltılması veya ölümlerin önlenmesinin yanında popülasyon yoğunlukları, habitat kullanımları gibi türlere ait yapılacak çalışmalarda da kullanılabilmektedir.

Kırıkkale-Çankırı Karayolu'nda YHAÇ'leri önlemek için yaban hayatı ya da ekolojik köprülerin yapılmasının hem ekonomik hem de ekolojik olarak uygun olmayacağı söylenebilir. Bu alanda YHAÇ’leri önlemede en akılcı yaklaşım iyi planlanmış bir YHUL kullanımıdır. 
Çalışma alanımız olan Kırıkkale-Çankırı karayolu üzerinde kullanılan ve toplamda 10 adet olan YHUL ile YHAÇ'lerin meydana geldiği kaza noktaları incelendiğinde alanda kullanılan bu levhaların hem konum hem de sayı olarak yetersiz oldukları görülmektedir (Şekil 7).

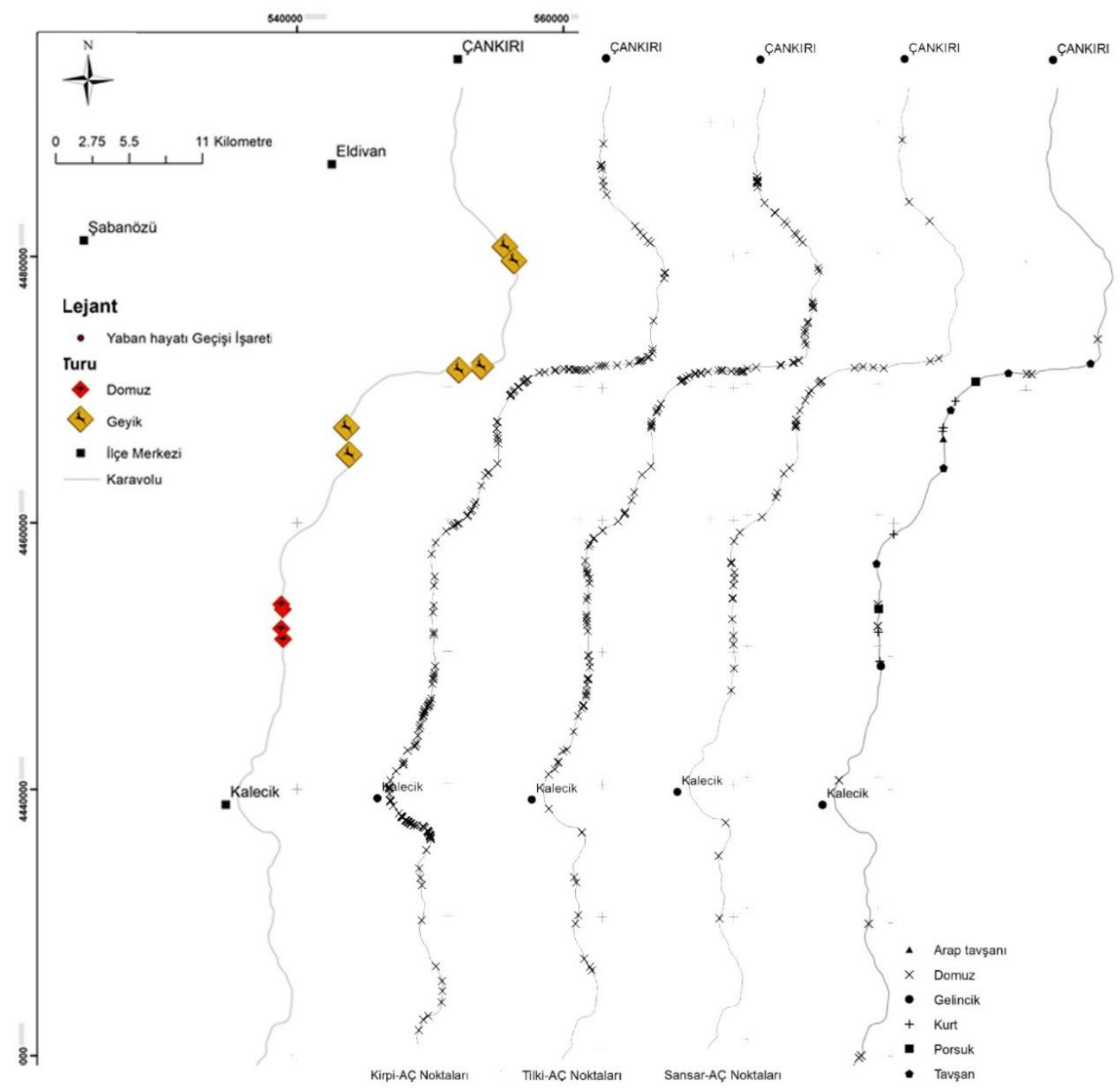

Şekil 7. Kırıkkale-Çankırı karayolunda YHUL’ler ile YHAÇ’lerin analizi.

Her ne kadar bu levhalar genel bir yaban hayatı varlığını ve aktivitesini tasvir etse de yaban domuzu figürlü levhaların konuldu alanların en çok yaban domuzu kazasının olduğu noktalara denk geldiği dikkate çekmektedir. Ancak toplamda 12 yaban domuzu kazasından sadece 4 adedi bu levhalar arasında ya da yakında meydana gelmiştir. Karayolundaki mevcut 10 adet YHUL'nin konumları incelediğinde alanda kaydedilen 389 adet kazanın yaklaşık olarak 52 adedi bu levhalar ile ilişkili olduğu görülmektedir. Bu da toplam kaza sayısının yaklaşık olarak \%13,5'ine denk gelmektedir. Burada unutulmaması gerek konulardan birisi de kazaların levhalara olan mesafeleridir. Kazalar levhalara ne kadar yakın ise o levhanın konumunun doğruluğu tartışılmalıdır. Nitekim 39.2-39.6 km'ler arasındaki levhalarda meydana gelen domuz kazalardan 2 tanesi levhalara çok yakın noktada iken 54.8. km'deki levhanın yaklaşık 10-20 m. yakınında bir kurt kazasının olması bu noktalardaki levhaların yerlerinin uygun olmadığını göstermektedir. Çünkü bu mesafeler sürücülerin önlem almalarına yetecek uzunlukta değildir. Yine şekil 7 de görüldü üzere YHAÇ’lerin yoğun olduğu bazı alanlarda hiç levha olmadığı da dikkati çekmektedir.

Dünya üzerinde çoğu standart olan bu YHUL'lerin araştırma alanımızda da bulunduğu ancak bunların konumlarının uygun yerde ve miktarlarının gerekli sayıda olmadığı söylenebilir. YHUL'lerin uygulanacağı noktalar tehlike alanlarına (kör noktalara) farklı uzaklıklarda olabilir. Nitekim Drory ve Shinar (1982) yaptıkları çalışmada, sürücüleri bir YHUL'yi geçtikten 200 metre sonra durdurmuşlar ve sürücülerin sadece \%5-10'unun bu levhayı hatırladığı ya da gördüğünü belirlemişlerdir. 
Türkiye'de YHAÇ'lerin önlenmesi ve YHUL'lerin konumlanması amacı ile öncelikli olarak bu konu ile ilgili bir veri tabanın kurulmasına ihtiyaç vardır. Her ne kadar Orman ve Su İşleri Bakanlığı (mülga-yeni adı Tarım ve Orman Bakanlığı) 2014 yılında resmi olarak hayata geçirdiği KARAYAP (Karayolları ve Dışında Yaban Hayvanı Ölümleri Projesi) ile YHAÇ’lerin izlenmesi ve değerlendirilmesini yapmayı hedeflese de geçen süre içinde herhangi bir çalışma gerçekleştirilememiş ya da sonuçlar kamuoyuna duyurulmamıştır. Dünya'da farklı ülkelerde YHAÇ verileri internet üzerinden toplanmakta ve kullanıcılarına sunulmaktadır. Çekya'da AnimalVehicle Collision isimli web sitesi bunun en iyi örneklerinden birisidir (URL-03). Bu web sitesi devreye girmeden önce ülkede karayolu ve demiryollarındaki YHAÇ'lerin sayısı bilinmemekteyken sitenin kurulmasından sonra gelen veriler ile bu alandaki eksikler büyük ölçüde kapatılmıştır. Bu site, bireysel avcılar, av dernekleri, ormancılar, polis, sigorta şirketleri, yol yöneticileri, çevreciler ve kamuoyuna kadar çeşitli kullanıcılar tarafından kullanılmaktır. Her yeni veri girişi ile modellemeler yapılmakta ve kazalar arkasındaki ilişkiler ortaya çıkarılmaktadır. Düzenli olarak analiz edilen verilerin kısmi sonuçları her iki yılda bir yayınlanmakta ve ülkedeki YHAÇ için kör noktalar belirlenmektedir.

Bu bağlamda öncelikle kara yollarındaki YHAÇ'leri önlemek için kör noktalar belirlenmeli, trafik yoğunluğu ve trafik akış hızına bağlı olarak bu noktalardan uygun olanlara YHUL'ler konulmalıdır. Levhaların konulacağı yerler belirlenirken YHAÇ'lerin yoğun olduğu noktalar yanında YHAÇ’ye sebep olan hayvan türü de oldukça önemlidir. Nitekim bir karayolunun belirli bir kısmında çok fazla YHAÇ görülebilir ancak bu noktada kazaya karışan yaban hayvanın türü gerek popülasyon gerekse de ekolojik açıdan tolere edebilecek bir tür olabilir. Örneğin araştırma alanımızın 20-30 km bölümünde 49 YHAÇ belirlenmiş olup bunun 39 adedi kirpi, 9 adedi tilki, 1 adedi ise yaban domuzudur. Bu bölüm orta yoğunlukta YHAÇ olan bir kısım olsa da ağırlıklı olarak kirpilerin kazaya karışmasından dolayı önemli derecede ekonomik ya da ekolojik kayıplara sebep olmayacaktır. Buna karşın yolun 30-40. km.bölümünde 5 yaban domuzu, 2 kurt ve 23 adet tilkinin kazaya karışması bu bölümü özellikle ekonomik kayıplar açısından önemli bir hale getirmektedir. Çünkü bu türler büyük memeli yaban hayvanları olup YHAÇ sonucunda farklı boyutlarda maddi kayıplara ve hatta yaralanmalara ya da can kayıplarına sebep olmaktadır. Dolayısı ile bir karayolunda büyük memeli yaban hayvanlarının daha fazla kazaya karıştığı ya da kara yolunudaha fazla kullandığı noktalar kör nokta olmasa dahi yaban hayatı uyarı levhaları ile sürücülere bildirilmelidir.

YHUL'lerin yerine karar vermede önemli kriterlerden biri de o alanda yaşanan yaban hayvanı türünün küresel ya da yerel ölçekli statüsüdür. Örneğin küresel ölçekli nesli tehlike altında olan bir türün yaşam ortamından geçen bir karayolunda mutlak suretle yaşam alanı boyunca uyarı levhalarının asılması türün korunması açsından oldukça büyük önem taşımaktadır. Bu tip yerlerde kullanılan levhalar mutlaka türe özel figürlerin olduğu levhalar olmalıdır. Örneğin çizgili sırtlanın (Hyena hyena) yaşam alanlarındaki karayollarına bu türün figürünün olduğu levhalar dikilmelidir. Çalışma alanımızda bu nitelikte bir yaban hayvanı türü olmasa da mevcut türlerden porsuk ve kurt diğer türlere göre daha nadir türler arasında yer almaktadır.

YHUL'ler karayolunun kenarına dikilirken dikkat etmek gerek bir diğer konuda bu levhaların kör noktalara olan uzaklıklarıdır. YHUL'ler tehlikenin olduğu noktalardan ya da potansiyel tehlike alanlarından en az 2. km önceden başlayarak dikilmeli ve her biri diğerinin yarısı kadar mesafede olacak şekilde uyarı levhaları tekrarlanmalıdır. Yani ilk levha kör noktaya en az 2 km., 2.si 1 km., 3. sü 500 m., 4. ise 250 metre uzakta olacak şekilde dikilmelidir. Bu şekilde 4 YHUL konulması hem sürücülerin dikkatini toplaması hem de hızlarının azaltılması açısından önemlidir. Bu maksatla YHUL'lere hız sınır işaretlerinin de eklenmesi faydalı olacaktır. Ancak yolun şekli ve yapısına bağlı olarak bu mesafelerin değişebileceği de unutulmamalıdır. Örneğin açık alandaki bir karayolunda bu mesafeler uygun iken orman içinde daha sık aralıklarla levhaların dikilmesinde fayda vardır. Bu noktada unutulmaması gerek önemli bir husus YHUL'lerin hiçbir zaman trafik hacmini azaltmayacağı ya da yaban hayvanlarının yoldan geçerken araçlardan kaçınmasını sağlamayacağıdır. Bu levhalar sadece sürücüleri uyarmak ve onların önlem almalarını sağlamak amacı ile yerleştirilmektedir.

YHUL'lerin şekli ve renkleri de istenilen etkinin sağlanması açsından oldukça önemlidir. Türkiye'de çoklukla kırmızı çerçeve, beyaz ya da sarı zemin ve siyah hayvan figürü kullanılırken farklı ülkelerde farklı tipte levhalar kullanılmaktadır (Şekil 8). Bu noktada kullanılacak olan uyarı levhalarının kör noktalara olan uzaklıklarına göre farklı renklerde olması da sürücüler üzerinde daha fazla etki yapabilir. Örneğin kör noktaya en uzak mesafedeki levha (2 km.) yeşil iken diğer levhalar sırası ile sarı $(1 \mathrm{~km}$.), turuncu $(500 \mathrm{~m}$.) ve kırmızı $(250 \mathrm{~m}$.) renklerde olabilir.

YHUL'lere rağmen YHAÇ'lerin yoğun olarak devam ettiği noktalarda ise yaban hayvanını karayolundan uzaklaştıracak farklı önlemler alınmalıdır. Bu amaçla yol kenarlarına tel çitlerin yapılması, yaban hayvanlarının geçebileceği standartlarda doğal alt geçitlerin düzenlenmesi, uyarı levhalarına ek olarak büyük reklam panolarının ve 1şıklı levhaların kullanılması YHAÇ’lerin azaltılmasında önemli katkı sağlayacaktır. 


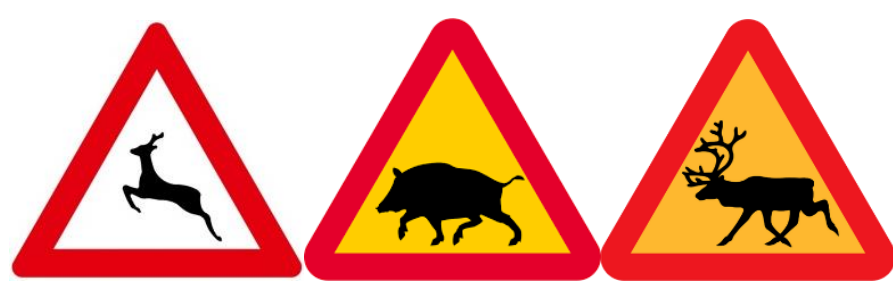

a

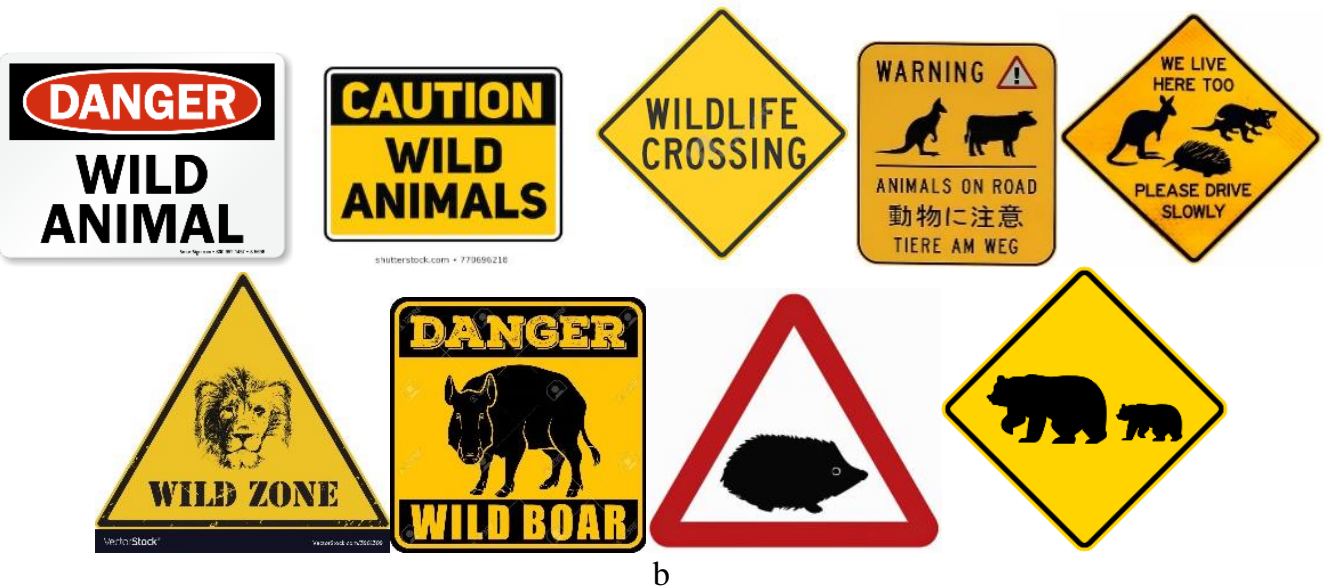

Şekil 8. YHUL a) Türkiye'de kullanılan b) Farklı ülkelerde kullanılanlar (URL-04).

\section{Kaynaklar}

1. Barthelmess, E.L. ve Brooks, M.S. 2010. The influence of body-size and diet on road-kill trends in mammals. Biodiversity and Conservation, 19(6): 1611-1629.

2. Bissonette, J.A., Kassar, C.A., Cook, L.J. 2008. Assessment of costs associated with deer-vehicle collisions: human death and injury, vehicle damage, and deer loss. Human-Wildlife Conflicts, 2(1): 17-27.

3. Bond, A.R.F., Jones, D.N. 2013. Wildlife Warning Signs: Public Assessment of Components, Placement and Designs to Optimise Driver Response Animals (Basel), 3(4): 1142-1161. doi: 10.3390/ani3041142

4. Beben, D. 2012. Crossings for animals - an effective method of wild fauna conservation. Journal of Environmental Engineering and Landscape Management, 20:86-89

5. Bruinderink, G.G., Hazebroek, E. 1996. Ungulate traffic collisions in Europe. Conservation Biology, 10(4): 1059-1067.

6. Clevenger, A.P., Chruszcz, B. Gunson, K.E. 2003. Spatial patterns and factors influencing small vertebrate fauna road-kill aggregations. Biological Conservation, 109:15-26.

7. Conover, M.R., Pitt, W.C., Kessler, K.K., DuBow, T.J., Sanborn, W.A. 1995. Review of human injuries, illnesses, and economic losses caused by wildlife in the United States. Wildlife Society Bulletin (1973-2006), 23(3), 407-414.

8. Drork, A., Shinar, D. 1982. The effect of roadway enviroment and fatigue on sing perception. Journal of Safety Research, 21:25-32

9. Dussault, C.M., Roulin, M., Courtois, R., Ouellet, J.P. 2006. Temporal and spatial distribution of moose-vehicle accidents in the Laurentides Wildlife Reserve, Quebec, Canada. Wildlife Biology, 12:415426.

10. Elmeros, M., Christensen, T.K., Lassen, P. 2011. Concentrations of anticoagulant rodenticides in stoats Mutela erminea and weasels Mustela nivalis from Denmark. Science of the Total Environment, 409:2373-2378.

11. Ferreras, P., Aldama, J.J., Beltrán, J.F., Delibes, M. 1992. Rates and causes of mortality in a fragmented population of Iberian lynx Felis pardina Temminck, 1824. Biological conservation, 61(3): 197-202.

12. Ford, A.T., Fahrig, L. 2007. Diet and body size of North American mammal road mortalities. Transportation Research Part D: Transport and Environment, 12(7): 498-505.

13. Forman, R.T.T., Alexander, L.E. 1998. Roads and their major ecological effects. Annual Reviews Ecology and Systematics, 29:207-231. 
14. Gilbert, S. L., Sivy, K. J., Pozzanghera, C. B., DuBour, A., Overduijn, K., Smith, M. M., Zhou, J., Litle, J.M., Prugh, L. R. 2017. Socioeconomic benefits of large carnivore recolonization through reduced wildlife-vehicle collisions. Conservation Letters, 10(4): 431-439.

15. Gosselink, T. E., Van Deelen, T. R., Warner, R. E., Mankin, P. C. 2007. Survival and cause-specific mortality of red foxes in agricultural and urban areas of Illinois. The Journal of Wildlife Management, 71(6): 1862-1873.

16. Huijser, M. P., Mosler-Berger, C., Olsson, M., Strein, M. 2015. Wildlife warning signs and animal detection systems aimed at reducing wildlife-vehicle collisions. Handbook of Road Ecology, 198-212.

17. Huijser, M.P., Bergers, P.J.M. 2000. The effect of roads and traffic on hedgehog (Erinaceus europaeus) populations. Biological Conservation, 95:111-116.

18. Huijser, M.P., Fuller, J., Wagner, M.E., Hardy, A. Clevenger, A.P. 2007. Animal vehicle collision data collection. A synthesis of highway practice. NCHRP Synthesis 370. Project 20-05/Topic 37-12. Transportation Research Board of the National Academies, Washington DC, USA.

19. Iuell, B. 2003. Wildlife and traffic-a European handbook for identifying conflicts and designing solutions. In The XXIInd PIARC World Road CongressWorld Road Association-PIARC.

20. Jaarsma, C.F., van Langevelde, F., Baveco, J.M., van Eupen, M., Arisz, J. 2007. Model for rural transportation planning considering simulating mobility and traffic kills in the badger Meles meles. Ecologicalin Formatics, 2:73-82.

21. Joyce, T.L. Mahoney, S.P. 2001. Spatial and temporal distributions of moose-vehicle collisions in Newfoundland. Wildlife Society Bulletin, 281-291.

22. Kramer-Schadt, S., Revilla, E., Wiegand, T., Breitenmoser, U.R.S. 2004. Fragmented landscapes, road mortality and patch connectivity: modelling influences on the dispersal of Eurasian lynx. Journal of Applied Ecology, 41(4), 711-723.

23. Kruidering A.M., Veenbaas G., Kleijberg R., Koot G., Rosloot Y., Van Jaarsveld E. 2005. Leidraad faunavoorzieningen bij wegen. Rijkswaterstaat, Dienst Weg-en Waterbouwkunde, Delft, The Netherlands;

24. Lode, T. 2000. Effect of a motorway on mortality and isolation of wildlife populations. AMBIO: A Journal of the Human Environment, 29(3): 163-166.

25. Malo, J.E., Suarez, F., Diez, A. 2004. Can we mitigate animal-vehicle accidents using predictive models?. Journal of Applied Ecology, 41:701-710.

26. Romin, L.A., Bissonette, J.A. 1996. Deer: vehicle collisions: status of state monitoring activities and mitigation efforts. Wildlife Society Bulletin, 24(2): 276-283.

27. Sáenz-de-Santa-María, A., Tellería, J.L. 2015. Wildlife-vehicle collisions in Spain. European Journal of Wildlife Research, 61(3), 399-406.

28. Sarbello, W., Jackson, L. W. 1985. Deer mortality in the town of Malone. New York Fish and Game Journal, 32(2): 141-157.

29.Smith, D.J. 1999. Identification and prioritization of ecological interface zones on state highways in Florida. In: Evink, G.L., Garrett, P., Zeigler, D. (Eds.), Proceedings of the Third International Conference on Wildlife Ecology and Transportation. Florida Department of Transportation, Tallahassee.

30. Smith, D.J. 2003. Ecological effects of roads: Theory, analysis, management and planning considerations. University of Florida.

31. URL-01 https://www.sabre-roads.org.uk/wiki/index.php?title=Warning_Sign/Wild_Animals

32. URL-02.http://www.transportation.alberta.ca/Content/docType233/Production/65Wildlife Crossing_signs.pdf

33. URL-03. http://www.srazenazver.cz/en/

34. URL-04. https://www.google.com/search?newwindow

35. Vignon, V., Barbareau, H. 2008. Collisions entre véhicules et ongulés sauvages: quel coût économique. Une tentative d'évaluation. Faune sauvage, 279: 31-35.

36. Williams, A. F., Wells, J. K. 2005. Characteristics of vehicle-animal crashes in which vehicle occupants are killed. Traffic Injury Prevention, 6(1): 56-59. 